\title{
學術集談會演說要旨
}

\author{
（昭和 15 年 4 月 18 日表）
}

赤血球沈降速度卜肺結核ノ經過

邪田幸雄

川上立太郎

褔井覺

重 瀷太 郎

昭和 14 年中. 當附屬醫院 二在院七ル 肺結核患者ニッキ. 赤沈キ中心トシテ種 々統計的觀察キ行ツタ. 赤沈ハWestergren 氏法二據り。且.ツ中等價探ツタ。 溫度八恒溫裝置于用七, 或八宝溫計測八 値キ吾カ醫局，溫度補正表二依り。攝氏 $20^{\circ}$ 二換算ス. $10 \%+1$ 誤差範圍卜入。 先ヅ全患者 232 名ニッキ. 入院時赤沈值 八本均求メテ見ルト。男女卜モ 53 强 キ示シ. 總本均值 53.3 郎チカナリ病機， 進ンダ者多キチ知り得ル。程度別二見レ バ正常値及ビ移行値 $3.8 \%$. 高度促進八 $55.3 \%$ ノ過牛數キ占メテキル. 次二 3 ケ 月後, 病勢轉歸二於テ八。入院時高度促 淮者ノ約 $1 / 332.4 \%$ 八死亡. 更二 6 ケ月 後 ノ狀態デハ約 $1 / 248.0 \%$ ガ死亡シテ + ル。

轅快退院スルモノハ 3 ケ月後. 6 ケ月 後何レニ於テモ、赤沈促進度/僅少ナル 程高众キ示シテキル。

吾々八肺結核患者二對シ。原則トシテ 2 週間二 1 度赤沈テ測定シテキルガ. 相 次グ 2 回ノ測定デソノ差 20 䊗以上アル 時ハ。大體病勢モりレニ應ジテ變化シテ キルコトチ觀察シ得タ。郎チ赤沈減少七
ルモノノ $65 \%$ ハ病勢暧快キ示シ. 反對二 赤沈增加七ルモモノ７1\%八病勢增㦞き 示ス. 然シ又一部病勢ト逆行スルモノモ 見ラレタ。

熱型モ亦．赤沈卜大體比例 シテ上昇乃 至下降入ル。コレォ更二前々间卜，差郎 チ1ケ月チオイテ差 20 粍アルモノニツ イテ兒ルトコレラ,關係八更二著明二ナ 几。

最後二死亡前赤沈值，變化キ見ルト。 83 例中明カ二遲延, 傾向丹示七ルモ， $62.5 \%$ ノ多キ二及ンダ. ソノ中移行值以 下二下レルモノハ 14 例 $16.8 \%$ デァル。 コレラ死亡前赤沈ノ遲延セルモノ 52 例 ニツイテ遲延開始ヨリ死亡汽，期間キ見 ルト.ソノ大多數 $78.8 \%$ 八牛月乃至 1 月 牛デアル。2 月以上二及ブモノ八極メテ 僅少 $5.8 \%$ デァッタ。病型デハ死亡前ナ 木高度促進二止ルモノ八沴出型. 混合型 二多ク. 遲延スルモノ八增殖型. 硬化型 二高率ナルコトチ認メ得タ。

ナホ. 他二. 赫卜血液像卜八關係习 モ胃タガ. 赤沈高度二促進スルニツレ. 白血球數增加シ。核左偏高度トナリ。淋 巴球.「エオジン嗜好白血球八減少乃至 消失スルキ確メ得タ。

固有竝二非固有宿主瞊器乳劑

ニテ處置セル犬十二指腸螼仔

盘ヨ非固有宿主ニ投與セシト

キノ滈高狀態二就イテ 
金、子澧 治

固有宿主贜器乳剂二テ處置セル犬十二 指腸蟲仔蟲 于非有固有宿圭 (家鬼.「ラ。 テ」。「マウス」)二投與シ。種々八時期二撲 殺シテ幼蛊，發有狀態テ觀察スル二幼犬 臟器乳剖二テ處置セルモノフ與へルトキ 幼蟲, 大サ八培養滿 5 日目完熟被衰仔蟲 , 體長本均値 0.6133 m.m.(100雙) ヨリ大 ナ゙モノ八何レノ動物二於イテモ $90 \%$ 以上ニシテ培養仔䖪最小值 $0.540 \mathrm{~m} . \mathrm{m}$. ヨリ小ナルモノ一ツモナシ. 又家鬼二投 與七シモノニ於イテ八原器口衰キ形成入 几迄二發有七ルモ，多數發胃七り。

然ル二壯犬臟器乳剂二テ處置セルモモ, 投與スルトキ本均值 0.6133 m.m. ヨリ 大ナルモノ八家鬼 $53 \%$ 。「ラッテ」 $70 \%$ 。 「マウス」95\%，老大臟器乳剂二テ處置， モノニテハ家鬼 $33 \%$.「ラ,テ」 $65 \%$ 。「、 ウ久」 $65 \%$ ニテ幼犬臟兴乳劑處置, モ ノョリ著シク小ニシテ. 原兴口襄キ形成 ス几迄二發有七几・ヒ, +ク。培養仔䖵， 大サ, 最小値ヨリ小ナルモノ スラ多少認 メタリ。

次二非固有缩主藏器乳剂 (家鬼。「ラ。, テ」・「マウス」)二テ處置七ルモノ头記

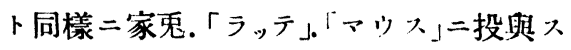
ルトキ27例，顀驗二於イテ幼䖵，體長 八培養仔䖧體脣本均値 0.6133 m.m.. リ 大ナルモノ八大牛 $80 \%$ 以下ナリ. 稀 $=90$ \%以上ノモノチ見タリ。原器口赛キ形成 スル迄二發有七ルモノモ極入ラ稀二見ラ レ. 培養仔䖧體長最小值 0.540 m.m..$\exists$ 》 小ナル幼蟲モ多少兒ラレタリ。之周有 缩主臟器乳劑二テ處置セルモノ二比スル 二壯犬. 老犬二テ處置七ルモ,トハ大差: ナケレドモ。幼犬贜器孚劑二テ處置七ル モノトハ大ナル相違キ示七り。

\section{犬ノ各種硪器乳劑 犬十二指晹仔䖵 白鼠二經口 感染セ儿際ノ體內移行狀況}

長 谷 部一郎

犬十二指晹蟲仔蟲丹白鼠二經口的二感 染七シムル時八仔蠱八消化管壁き通過シ テ肺循環于營之。最後二頸部笳肉 $⿻ コ 一$ 部腹部四肢等, 筋内内二移行入ルモノ二 シテ劣此, 際感染動物, 幼弱ナルモノ程 感染率高シ。

次二犬，各種蔵器乳劑二テ一定時間處 置七ル仔蟲习同ジク經口感染七シムル時 八仔蟲, 體內移行狀況八無處置仔蟲于 感染七シ場合卜些力相違アル結果㸷 ז゙。

\section{賽驗方法。}

仔蟲八滿 5 日間 $28^{\circ} \mathrm{C}$ ，艒卵器內二培 養シテ得タ儿新鮮ナル仔蟲习使用セり。 乳劑入牛後 10 日妇》2. 3 ケ月以內，幼 犬习撲殺入ル力或八外科的手術ニヨリテ 目的八臟兴, 一部及八全部キ剔出シ。直 チニリンゲル氏液ォ以ラ 10 倍乳劑キ作 成シ. 此/中二所要, 仔蟲斗投入 $337^{\circ} \mathrm{C}$ , 卵酣器內二 2 時間乃至 4 時間放置シ夕夕 儿後. 各例共一千雙，仔蟲寻投與セり。 仔蟲檢出法ハ「ベールマン」氏仔蟲分雄法 キ以テセリ。

其結果. 胃. 小腸. 肝贜. 腸間膜. 脾 臟. 肺藏. 筋肉等, 各種乳劑中最モ著明

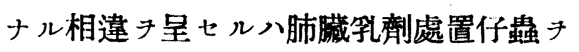
感染七シ場合ナリ，郎于無處置仔虽感染 二於テ八消化管二テハ感染後 1 週日目二， 於ラ既二全ク仔蟲フ認メラレズ。呼吸器 二テ八發見仔䖵數,最モ多12 日目”檢 出仔蟲數八 3 例本均 265 雙二シテ投與數 二對入儿百分率八 $26.5 \%$ (以下投與\%卜 記入) 檢出總數二對人 几百分桃， $67.3 \%$ 
(以下檢總\%下記入)。其他，臟器師 于腸 間膜. 肝藏. 心贜. 脾藏. 留臟等二於 テハ其ノ發胃仔蟲數立立二仔蟲移行狀況二 於テ乳剂處置仔蟲, 場合二比シ大差ナ シ。筋肉二テハ感染後 2 速日後二於テ 八檢出仔蟲數 3 例本均 139 雙. 投與\% 13.9 檢總 $\% 100$ チ示入。

然ル二肺臟乳劑處置仔蟲感染二際シテ 八消化管二於テハ 2 逗日後劣 3 例本均 9 雙.郎 チ投與 $\% 0.9$. 檢總 $\% 71.8$-示入. 呼吸器二於ヶル 2 日目，仔蟲數ハ止均 124 雙. 投與 $\%$ 12.4. 檢總\% 42.6 二シテ 前者ヨリ透二少シ。筋肉二於テ八各期間 チ通ジテ仔䖵數甚ダ少ク 2 愿日目二於ケ ル本均數ハ 4.3 集隻. 投與 $\% 0.4$. 投總\% 28.1 チ示入。

結 諭

（1）犬十二指腸蟲仔䖵／白鼠二於ケル 經口感染ニテハ幼弱ナル白鼠程感染率高 シ。

(2) 犬ノ各種藏器乳劑止以テ一定時間 處置セル仔蟲ハ消化管內二長ク川: リ筋 肉へ, 移行能力キ抑制サル、モノニシ テ. 此ノ事實八肺臟乳剂處置低蟲二於テ 最モ顯著ナリ。

（3）犬十二指腸蟲仔蟲八固有缩主，臟 器乳劑キ以テ…定時間處置入ルコトニョ リ特殊, 性能丹賦與サル、モノノ如シ。

\section{好氣的細菌培養液二浸セル不反應 性電極ノ電位綾化二就イテ}

\section{稫 見 秀 雄}

Michaelis ハソノ著書二於テ,, die Art und Weise, mit welcher Elektroden auf molekularen Sauerstoff ansprechen, ist so individuell verschieden, daB man noch schwerer reproduzierbare Werte erhält als bei den Farbs- toffen. Die Messung des aeroben Potentials an einer Elektrode hat daher viel weniger Sinn als die mit einem Farbstoffindikator."ト韭イテキルガ. ソレニモ不拘. 細菌培養液, 好氣的電極 電位ガ相當研究對象トナルノ八劣或範圍 內ニテ Reproduzierbarkeit ガアル䉆デ アリ。隨ツテコノ範喡キ認鿆入ル事ハ必 須ノ事デァル。著者八产空管電位差計チ 用七于細䒩培養液，好氣的電極電位子测 定シ.電位-時間一曲線-觀察シタガ.コノ 場合。问一液网二浸七儿同種電極間二モ 僿、相常ノ相違ガ見ラレ。+ +0.1 V. 程度 八相違八. 特二電位變化 急激ナ場所デ 八稀デハナイ。斯ル求沽考虑入ル事ナシ

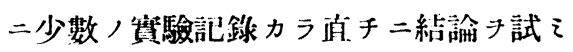
ルノ八色險デァリ. 先人ノ報告中二モ此 ノ種, 誤算カト思ハレルモノガ往々二兒 ラレル。例へバ Sulfanilamide ガ細茵,

第 1 閚 電位-pH- $\mathrm{pH}$-線

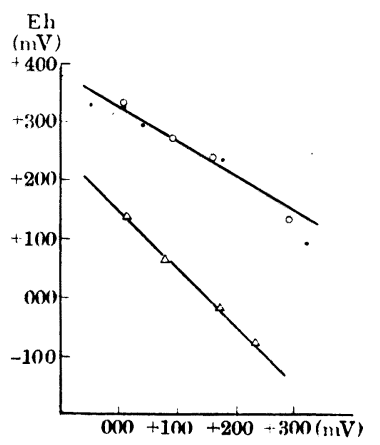

glaselektrodenpotential gegen Standardacetat.

$$
\begin{aligned}
& \text { ( ) ....㳦菊糖 Bouillon } \\
& \text {.....㔨通 Bouillon } \\
& \triangle \cdots \cdot \text { 萢萄糖-Bouillon , 鴚 } \mathbf{A} \\
& \text { 菌(山崎株)24時間培養液 }
\end{aligned}
$$


培養液二及ボス影传二關スル Warren 等ノ觀察ハコノ種ノモノデハナイカ。コ ノ點二關シテハ細菌ノ型別ニヨル終極電 位 相違二關スルBurrows等及ビ Gillepsie等ノ業績八尊重サルベキデアル。及 Ward 八電位一時間-曲線, Reproduzierbarkeit 二. 培養液, Homogeneität ガ.

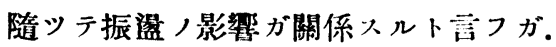
著者が. 大原茵， $\mathrm{R}$ 型ニテソ，發育， Heterogenität，僬力。振淲十キ場合二 八振泚入ル場合二比シ非常二 Reproduzierbarkeit 八少ナイ結果子得タノ八面 白イ事卜思フ。仯又培養カ酸形成ス儿場 合ハシカラザル場合二比シ終極電位が高 イガ. 之八著者ガ得タ電仙-pH-線(第 1 圖) ヨリ胃テ當然ノ事デアラウ。

\section{一例ノ Lipschütz 氏急性陰部 溃湯ニ見出サレタル細菌叢 二就イテ 二神由紀苶 林阿安}

本症ハ 1913 年 Lipschütz 二依り初メ テ明確二記載サレタ疾患デァッテ何等， 誘因ノ認メラレズシテ若年ノ婦人ノ陰部 二發生三甚シキ疼痛 7 件ッテ組織，崩 壤于來三潰瘍子形成入ル非性病性, 一 獨立疾患デアッテ其溃瘍面ヨリハ常 Lipschütz ，所謂 B. crassus ナル「グラ ム」陽性ノ桿菌ガ胃出サレ之が㧫原菌ナ リト考へラレラキル。私共八最近本㱏，

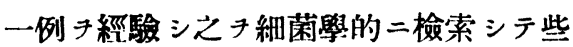
力諸家ノ報告ト異ツタ成縝キ得タノデ之 き報告シタイ。

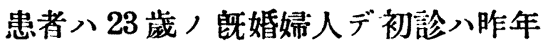
7 月 3 日. 突然激痛 アル外陰部及ビ子官 脭部附近, 潰瘍形成, 外二口腔粘膜二八
「アフタ」樣ノ小潰瘍ガ多數存在シ發热が アリ其ノ經過中關節痛ノ後デ四肢ノ伸僋 二小膿疮ノ發生き見屚了再發シテ全治迄 二5 ケ月子要シタ。，伊東氏反應.フライ 氏反應陰性. 各種, 徽毒血清反雇八總テ 陰性. マント一氏結核反應中等度陽性. シック反應弱陽性デ赤血球沈降速度,促 進卜輕度, 淋巴球增多症キ示シタ。

患考二八多量,膿樣,帶下ガアッテ腟 ，清泒度第 3 度. 酸性度 6.4 デ胵桿菌子 證明七ズ再三人检查二モ゙拘ラズ外陰部潰 瘍及ビ口膑粘膜,小溃癔ヨリ B. crassus (Lipschütz) 子證明シナカッタ。好氣性 二純培養シ得タ菌種ハ陰部潰瘍面及ビ臆 カラハ 2 種ハ「コリネバクテリウム」，溶 血性黃色葡萄狀球菌及七゙非溶血性白色葡 菌. 口腔ノ潰場カラ八肺炎雙球菌. 溶血 性黃色葡萄狀球菌. 非溶血性白色葡菌. 四 連球菌ガ主ナルモノデアッタ。

培養二ハ荒川氏「テルリット」加血液寒 天本板及ビ牛血液寒天本板于用七。時二 肝臟肝片「ブイヨン」增菌き行七更二之 チ前記, 2 種，本板培養基ニ移シテ 24 時間乃至 48 時間 $37^{\circ} \mathrm{C}$ ，晸卵器二納メ之 ヨリ各種ノ集落チ出來ルダケ洩レナク钧 菌シテ分離培養タ得ルニ努メタ。

又同時二病筃力ラ數枚ノ塗抹標本キ作 リ「グラム」染色及ビ Löffler 氏「メチレ ン」青單染色. Neisser 氏異染體染色及 ビ Ziehl-Gabbet 氏結核菌染色き施シ一 方其ノ分泌物 暗視野,下二鏡检シタ。

此ノ潰瘍面ヨリノ分泌物チ暗視野二テ

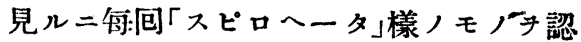
メズヌ運動ノアル菌及ビ大ナル長桿菌き 見ナ゙カツタ。陰部潰瘍面及ビ脭ヨリノ塗 抹染色標本デハ無數ノ白血球ノ間二多數 ノ「グラム陽性ノ大. 小球菌「グラム」陽 
性ノ棍棒狀或八指開狀ノヤ、長イ小桿菌 ガ胃ラレ. 欢グラム」陰性ノ小桿菌が少 數アッタガ「グラム」陽性ノ大桿菌タル B. crassus 八終始之ョ發見シ得ズ又抗酸 性菌モ存在シナカッタ。培養二依ッテ得 タ菌種八陰部潰瘍面站二胵, 兩者カラ共 二同ジク每回 2 種 ノ「コリネバクテリウ 厶」溶血性黃色葡菌及非溶血性白色葡菌 デアッタ。

傳研細谷研究室二於テハ 數年來「コリ ホバクテリウム」二就キ各方面ヨリ之き 系統的二研究中デアルガ. 分離培養二使 用七ル荒川氏培地八細谷教授指導,下二 皏究宝同人タル荒川哲氏ノ考案二カ、ル 「コリネバクテリウム」屬/分離培養二八 甚ダ優秀ナ培養基デアル。

此等, 分離七ル細菌群中特二其中， 「コリネバクテリウム」二就テノ生物學的 立二免疫學的性狀, 詳細八後日之き原著 トシテ發表ノ豫定デァルガ此患者ハ「ヂ フテリア」ノ獭防注射テ受ケタ事モナク 及「ヂフテリア」羅患シタコトガナイニ モ拘ラズ其ノ血清中ノ「ヂフテリア」抗 毒素量八 Römer 氏測定法デ $1 / 5$ A.E. デ 健康人ノソレヨリモ高ク. 又分雄サレタ 「コリネバクテリウム」ノノ一株八馬血 液寒天本板 48 時間培養二於テ溶血睘か 著明デ娧氣性二モ發有良ク。血液寒天. Löffler 氏凝固血清培地二八發有甚ダ可 良. 普通寒天二ハヤ、不良ノ細長桿菌デ Neisser 染色デ著明ナ異染體ナ有シ。松 葉狀又ハ指開狀 配列テナシ。「ゲラチ ン」。凝固血清テ液化七ズ牛乳き凝固セ シメズ.「インドール」反應陰性. 10\%牛血 液加寒天本板二於テハ 24 時間後灰白色. 牛透明. 正圓形デ隆起 シ表面滑澤. 光澤 ル小集落テ作リ．其周圍二溶血き認メル
ガ時間ノ經過卜共二溶血睘八更二著明卜 ナリ培養基面ヨリヤ、陷浔七儿如キ扁本 ノ大集落キ作ル。荒川氏「テルリ,ト」血液 寒天本板デハ「ヂフテリア」菌，mitis型 二近イ發有チナシ. 24 時間デハ帶青黑色 キ呈シ.次第二且黑色トナル表面滑澤. 光 澤アル圓形集落キ作ル. Martin-bouillon デハ 48 時間後. 菌膜チ作り顆粒狀. 微細 ナル沈澱キ生ジ中間層入透明デアル。

本菌ハ海猽. 家鬼. 及ビ「マウス」二對 シ認ムべキ病原性午缺クモ。糖分解八對 照タル毒素產生能チ有スル具性「ヂフテ リア」菌岡田株ト同ジゥ. glucose, laevulose, maltose 于分解シ saccharose, lactose, dulcit. inulin 及ビ mannite 八之チ分解シナカツタ。

細谷研究穼關屋氏法二依り此ノ「コリ ネバクテリウム」ト葡萄狀球菌毒素, 微 量卜チ體量 300 瓦前後, 淮猽睪丸賽質內 二注射スルト每常注射局所 $=3$ 週間後二

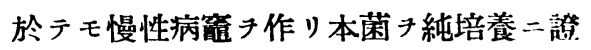
明七ラレタ。之二反シ强イ「ヂフテリア」 毒素二對スル抗毒性免疫き與へタ游猽， 睪丸賽質內二同樣葡毒, 微量卜本菌トチ 注射スルト全ク感染シナイカ及八感染シ テモ對照タル健康淮猽二於ケル族䇤二比 較スルト顯著ナル差違アルチ知ツタ。

本菌が「ヂフテリア」菌ノ戀異七ルモ， カ否カ二就テハ更二研究重示ルコト、 シ。向今後本症二遭遇シタラ此，藏き检 索シタイ。

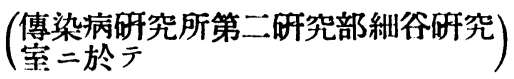

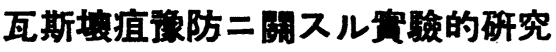 (第五啹) \\ 小田通男}




\section{須 藤 正 \\ 村田良介}

私共八前報二於テ B. welchii (Cl. perfringens), B. oedematiens (Cl. novyi), Vibrion septique (Cl. septicum), B. histolyticus (Cl. histolyticum) , Alumtoxoid 尹以テ夫々海猽及ビ「マウス」き 免疫三 1 回注射各週間，後二當該各菌， 肝片加肝藏「プイヨン」二於ケル全培養郎 于(生菌十毒素)，種々ナル量註射入ル コト二依ッテ感染防禦上相當效力アル免 疫丹生ズルコトキ認メ。次デ上記瓦斯壤 疽菌ノ 2 種及ビ 3 種, Toxoid 丹混合三 同樣ナ方法キ以ラ混合 Alum-toxoid 尹 作り海猽及ビ「マウス」き免疫スルトキ。 免度二用七夕各菌，全培養二對シテ感染 防禦上有效ナルコトキ發表シタ。今回 B. novyi, Vibrion septique 及ビ $B$. tetani , Toxoid 于等量二混合三前報卜同樣ナ 方法ニテ Alum-toxoid チ作リコレチ以

B. welchii ，精製 Alum-toxoid，製法 細行. 官田法二低儿精製 Toxoid No.21

(原 Toxoid， $1 / 2$ 量二濃樎七几モ）

$700 \mathrm{cc}$

$$
\begin{aligned}
& \stackrel{+}{+} \mathrm{Na}_{2} \mathrm{HPO}_{4} \cdots 40 \text { c.c. } \\
& \left(37^{\circ} \mathrm{C}=\text { 加溫コノ際牛ズル白色絮狀, 沈澱 }\right) \\
& \text { ( 滤紙二テ滤過除去ス。pH } 7.6 \text { トナル } \\
& + \\
& 10 \% \text { 加里明㭲水溶液 } \cdots 35 \mathrm{c} \text {. . . } \\
& \left(\begin{array}{l}
37^{\circ} \mathrm{C}=\text { 加溫沈澱キ完全二生ゼシム } \\
\hdashline \text { 夜靜置 } \mathrm{pH} 5.0 \text { トナル }
\end{array}\right) \\
& \text { 遠心 }
\end{aligned}
$$

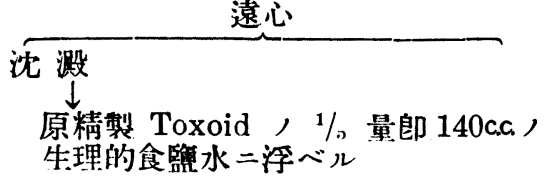

B. tetani /精製 Alum-toxoid € Bwelchii ，精製 Alum-toxoid卜同樣ナ方 法二テ作り。コノ各精製 Alum-toxoid 尹 等量二混合シタ混合精製 Alum-toxoid
テ海猽炛疫シ・ソノ各菌抗毒素ノ産生 狀態及ビ各菌き以テスル感染防禦試驗き 行七相當效果アル成績キ得タ。次二等量 二混合シタ B. welchii ト B. tetani , 原 Toxoid ヨリ出發シタ混合明㭲「ト キソイド」及ビ。兩者ノ精製「トキソイド」 ヨリ出發シタ混合精製明㮁「トキソイド」 キ以テ海猽免疫シタ成績キ報告スル。 Alum-toxoid 製法八各菌ノ强力ナル毒 素ニ「ホルマリン」⿻加へ Toxoid 化シ. 各菌, Toxoid 于等量二混合七ル混合 Toxoid $=10 \%$ 加里明䄷水溶液子加へ完 全二沈澱キ生ゼシメ．㕸日迄靜置後沈没 于數回水洗シタ後. 原 Tox id , $1 / 5$ 量l 隇菌生理的食監水二浮べ免疫二用七タ。 (混合粗. Alum-toxoid)。

次二精製 Alum-toxoid 八製法子略記 スレバ次）如シ。(當敎室永井氏，製法二 依ル)

キ以テ免疫二用七タ。 游猽八 $400 \mathrm{gr}$. 前後ノモノき用七.明禁 「トキソイド」2c.a (郎チ原「トキソイド」 10c.c相㗬量) 1 回皮下注射 行ツタ。全 
培養八肝片加肝臟「ブ $1 ヨ$ ン」. 生菌八 Zeissler 氏 $2 \%$ 葡萄糖加血液寒天本板, 㨀氣性培養ノモノチ用七タ。擎死七ル海 猽ハ注射局所或ハ心血ヨリ當該菌チ凡テ
證明シタ。又對照實驗ハ實驗, 都度多數 ノ健康海猽使用シタ。 實驗成績ノ一部き次ノ通り表二示ス。

第 1 表 B. novyi, Vibrion septique, B. tetani 混合 Alum-toxoid 2 cac (原 Toxoid，1/5 最 二濃縮セルモノ) 海猽皮下 1 间注射 5 週間後二心贜穿刺ニテ探血セル血清中ノ抗毒素测定

\begin{tabular}{|c|c|c|c|c|c|c|}
\hline 海猽番號 & \multirow{2}{*}{\multicolumn{2}{|c|}{$\begin{array}{l}\text { B. novyi } \\
<40 \mathrm{~m} \text {. l. d. }\end{array}$}} & \multirow{2}{*}{\multicolumn{2}{|c|}{$\begin{array}{c}\text { Vibrion septique } \\
80 \mathrm{~m} . \mathrm{l} \text {. d. }\end{array}$}} & \multirow{2}{*}{\multicolumn{2}{|c|}{$\begin{array}{l}\text { B. tetani } \\
>80 \mathrm{~m} . \mathrm{l} . \mathrm{d}\end{array}$}} \\
\hline No. 2 & & & & & & \\
\hline No. 3 & 80 & ", & 20 & ", & $>80$ & , \\
\hline No. 5 & 40 &.. & 80 & ", & $>80$ & , \\
\hline No. 6 & 40 & ", & 80 & ", & $>80$ & .. \\
\hline No. 9 & 40 & ," & 80 & .. & $>80$ & . \\
\hline No. 10 & $<40$ & .. & 80 & , & $>80$ & , \\
\hline No. 13 & 80 & , & 80 & ," & $>80$ & ", \\
\hline No. 14 & $<40$ & ", & 80 & , & $>80$ & , \\
\hline No. 16 & $<40$ & ," & 80 & $\because$ & $>80$ & .. \\
\hline No. 17 & $<40$ & ", & 80 & .. & $>80$ & " \\
\hline No. 18 & $<40$ & ,. & 80 & ", & $>80$ & ." \\
\hline No. 21 & $<40$ &. & $<20$ & " & $>80$ & ." \\
\hline No. 24 & 80 & ", & 80 & ", & $>80$ & $"$ \\
\hline No. 25 & 40 & ", & 80 & ", & $>80$. & ", \\
\hline No. 28 & $<40$ & .. & 40 & ." & $>80$ & ." \\
\hline No. 28 & $<40$ & ", & 80 & ", & $>80$ & ", \\
\hline No. 30 & 40 &. & 80 & $\because$ & $>80$ &. \\
\hline
\end{tabular}

備考 抗毒侕八血清 1 c.c. $>$ 中和シ得ル各菌毒素量. (「マウス」二数 スル m. l. d. 八倍數 $\ni$ 以テ表ス)

第 2 表 B. novyi, Vibrion septique, B. tetani 混合 Alum-toxoid 2 c.c. (原 Toxoid , $1 / 5$ 量二濃縮七ルモノ)海猽皮下 1 回注射 6 週間後二感染試驗

(10日閒観察)

\begin{tabular}{|c|c|c|c|c|c|}
\hline \multirow{2}{*}{ 感 染 菌 株 } & \multirow{2}{*}{ 全培養皮下注射 } & \multirow{2}{*}{ 海猽數 } & \multicolumn{2}{|l|}{ 結 } & \multirow{2}{*}{$\frac{\text { 果 }}{\text { 生存率 }}$} \\
\hline & & & 生存數 & 整死數 & \\
\hline \multirow{3}{*}{ B. novyi } & $\begin{array}{c}\text { (海璂=㩆スル) } \\
1 \text { m.l.d. }\end{array}$ & 5 & 5 & 0 & $5 / 5$ \\
\hline & 2 m.l.d. & 5 & 4 & 1 & $4 / 5$ \\
\hline & 10 m.l.d. & 5 & 3 & 2 & $3 / 5$ \\
\hline \multirow{3}{*}{ Vibrion septique } & 1 m.l.d. & 5 & 5 & 0 & $5 / 5$ \\
\hline & 2 m.l.d. & 5 & 4 & 1 & $4 / 5$ \\
\hline & 10 m.l.d. & 5 & 4 & 1 & $4 / 5$ \\
\hline \multirow{3}{*}{ B. tetani } & $1 \mathrm{~m} .1 . \mathrm{d}$ & 5 & 5 & 0 & $5 / 5$ \\
\hline & $10 \mathrm{~m} .1 . \mathrm{d}$ & 5 & 4 & 1 & $t / 5$ \\
\hline & $100 \mathrm{~m} .1 \mathrm{~d}$ & 5 & 4 & 1 & $4 / 5$ \\
\hline
\end{tabular}

借考 分母=使用海獏數 分子=生存數 
第 3 表 B. welchii, B. tetani 混合 Alum-toxoid 免没海冝血清中 抗毒素測定

\begin{tabular}{|c|c|c|c|c|c|}
\hline \multirow{2}{*}{ 免 疫 少 法 } & \multirow{2}{*}{ 海猽番號 } & \multicolumn{2}{|c|}{ B. welchii } & \multicolumn{2}{|c|}{ B. tetani } \\
\hline & & $\begin{array}{l}1 \text { 间注射 } \\
3 \text { 週間後 }\end{array}$ & $\begin{array}{l}1 \text { 间注射 } \\
5 \text { 週間後 }\end{array}$ & $\begin{array}{l}1 \text { 包注射 } \\
3 \text { 週閒後 }\end{array}$ & $\begin{array}{l}1 \text { 包注射 } \\
5 \text { 週間後 }\end{array}$ \\
\hline \multirow{11}{*}{$\begin{array}{c}\text { 混合精浆 Alum- } \\
\text { toxoid } 2 \text { c.c. } \\
\text { 海晖皮下 }\end{array}$} & No. 61 & 20 m.l.d. & $>40 \mathrm{~m} . \mathrm{l} . \mathrm{d}$ & $>80$ m.l.d. & $>320$ m.l.d. \\
\hline & No. 63 & $10-20$ & $40 \quad$ & $>80 \quad$. & $>320$ \\
\hline & . No. 65 & $>40$ & $>40$ & 40, & $>160$, \\
\hline & No. 66 & 0 & 0 & 20 & 80, \\
\hline & No. 75 & 0 & 0 & $40 \quad$ & 40 \\
\hline & No. 77 & 0 & 10 & $>80$, & 80 ", \\
\hline & No. 79 & 10, & 10 & $20 \ldots$ & $10 \ldots$ \\
\hline & No. 84 & 20 & $>40$. & $20 "$ & $20 "$, \\
\hline & No. 85 & 0 & 0 & 10 & 40, \\
\hline & No. 87 & 10 & 20 & $10 "$ & $20 \quad$, \\
\hline & No. 89 & 0 & 10, & 20, & 40, \\
\hline \multirow{12}{*}{$\begin{array}{c}\text { 混合粗 Alum- } \\
\text { toxoid } 2 \text { c.c. } \\
\text { 海猽皮下 }\end{array}$} & No. 5 & 0 & $10-20$ & 10 & $40 "$ \\
\hline & No. 6 & 10 & $>40 \quad$. & 0 & 40 \\
\hline & No. 8 & 0 & $10 \ldots$ & $20 \ldots$ & 40, \\
\hline & No. 9 & 0 & 0 & 10, & $20 \ldots$ \\
\hline & No. 11 & 0 & 10, & 20, & $>80$, \\
\hline & No. 14 & 10 & $20 \quad$. & 20, & $40 "$ \\
\hline & No. 15 & 10 & $10-20$ & 20 & $>80$ \\
\hline & No. 19 & 0 & $10 "$ & 0 & $20 \ldots$ \\
\hline & No. 21 & 0 & $20-40$, & 10, & 40, \\
\hline & No. 24 & 0 & $10 "$ & $>80$ & 160, \\
\hline & No. 25 & 10 & 20 & 0 & $>80$, \\
\hline & No. 26 & 10. & $20-40 \quad$. & 10, & $80 \ldots$ \\
\hline
\end{tabular}

備考 抗表㑽八血清 1 c.c. )中和シ得ル各菌瑇素最(「マウス」二對 スル m.l.d. 八倍数 $\ni$ 以テ表ス。)

第 4 表 A B. welchii, B. tetani 混合 Alum-toxoid 免疫海獏生菌注射感染試驗 (1 国免疫 5 週間後) (10 日間觀察)

\begin{tabular}{|c|c|c|c|c|c|c|}
\hline \multirow{2}{*}{ 免 投 j 法 } & \multirow{2}{*}{ 柋 染 藮 株 } & \multirow{2}{*}{ 生:菌腹部皮下 } & \multirow{2}{*}{ 海堔數 } & \multicolumn{2}{|l|}{ 結 } & 果 \\
\hline & & & & 生存數 & 獘死數 & 生存數 \\
\hline \multirow{4}{*}{$\begin{array}{c}\text { 混合精㹕Alum. } \\
\text { toxoid } 2 \text { c.c. } \\
\text { 海狽皮下 }\end{array}$} & \multirow[t]{2}{*}{ B. welchii } & $\begin{array}{c}\text { （海猽二對スル） } \\
1 \text { m.l.d. }\end{array}$ & 6 & 5 & 1 & $5 / 6$ \\
\hline & & 5 m.l.d. & 6 & 4 & 2 & $4 / 6$ \\
\hline & \multirow{2}{*}{ B. tetani } & 1 m.l.d. & 6 & 6 & 0 & $6 / 6$ \\
\hline & & 5 m.l.d. & 6 & 6 & 0 & - $6_{j / 6}$ \\
\hline \multirow{4}{*}{$\begin{array}{l}\text { 混合粗 Alum- } \\
\text { toxoid } 2 \text { c.c. } \\
\text { 海猽皮下 }\end{array}$} & \multirow{2}{*}{ B. welchii } & 1 m.l.d. & 6 & 3 & 3 & $3 / 6$ \\
\hline & & 5 m.l.d. & 6 & 4 & 2 & $4 / 6$ \\
\hline & \multirow{2}{*}{ B. tetani } & 1 m.l.d. & 6 & 5 & 1 & $5 / 6$ \\
\hline & & 5 m.l.d. & 6 & 5 & 1 & $5 / 6$ \\
\hline
\end{tabular}

備考 分母=使用海崲數 分子=生存數 


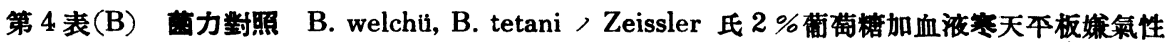
培美菌體 八菌力 海猽皮下注射

\begin{tabular}{|c|c|c|c|c|c|c|c|c|c|}
\hline 菌株 & 注 射 量 & 海猽番號 & 檍 & $\overrightarrow{\text { 日 }}$ & $\frac{三}{\text { 日 }}$ & 四 & $\frac{\text { 吾 }}{\text { 日 }}$ & 六 & 旨 \\
\hline \multirow{6}{*}{ B. welchì } & \multirow{2}{*}{$1 \mathrm{mg}$. } & No. 1 & + & & & & & & \\
\hline & & No. 2 & - & + & & & & & \\
\hline & \multirow{2}{*}{$0.2 \mathrm{mg}$. } & No. 3 & - & + & & & & & \\
\hline & & No. 4 & - & - & - & - & - & - & - \\
\hline & \multirow{2}{*}{$0.1 \mathrm{mg}$. } & No. 5 & - & - & - & - & - & - & - \\
\hline & & No. 6 & - & - & - & - & - & - & - \\
\hline \multirow{10}{*}{ B. tetani } & \multirow{2}{*}{$1 \mathrm{mg}}$. & No. 7 & + & & & & & & \\
\hline & & No. 8 & + & & & & & & \\
\hline & \multirow[t]{2}{*}{$0.2 \mathrm{mg}$. } & No. 9 & + & & & & & & \\
\hline & & No. 10 & + & & & & & & \\
\hline & \multirow{2}{*}{$0.1 \mathrm{mg}$. } & No. 11 & d & + & & & & & \\
\hline & & No. 12 & d & + & & & & & \\
\hline & \multirow{2}{*}{$0.02 \mathrm{mg}$} & No. 13 & $d$ & d & + & & & & \\
\hline & & No. 14 & $\mathrm{~d}$ & $\mathrm{~d}$ & + & & & & \\
\hline & \multirow[t]{2}{*}{$0.01 \mathrm{mg}$. } & No. 15 & $\mathrm{~g}$ & $\mathrm{~g}$ & $\mathrm{~g}$ & $\mathrm{~g}$ & $\mathrm{~g}$ & $\mathbf{g}$ & $\mathbf{g}$ \\
\hline & & No. 16 & $\mathrm{~g}$ & $\mathrm{~g}$ & $\mathrm{~g}$ & $\mathrm{~g}$ & $\mathrm{~g}$ & $\mathrm{~g}$ & $\mathrm{~g}$ \\
\hline
\end{tabular}

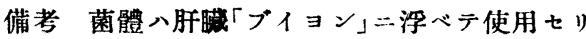
$+\cdots \cdot$ 定型的症状二テ䌘死， $-\cdots$ 生行 $d \cdots \cdots$ 著明ナル感染症狀 $\ni$ 表ス， $g \cdots \cdots$ 健康

表二示スガ如ク B. novyi，Vibrion septique, B. tetani , 3 者混合 Alumtoxoid 及ビ B. welchii, B. tetani $/ 2$ 者混合粗 Alum-toxoid 或八混合精製 Alum-toxoid チ以ラ. 海猽き免疫スルト キ. 之等ノ各菌二對シテ相當效果アル感 染防禦性免疫ノ出來ルコトキ認メタ。 (本研究費ノ一部八日本學術振興會, 補 助二依ルモノデアル) (傳染病研究所第二 的究部細谷研究宝二於テ)

Tuberkulin ノ有效成分ノ

$$
\text { 分離二就テ (第二報) }
$$

桑 嶋 謙夫

久保田久

量二私入牛型結核菌培養滤液力ラ結核 海猽へ，皮席物質卜致死物質明暸二分
䧸スルニ至ツタ次第キ報告シタ。(第 13 回聯合微生物學命記錄 161 頁．實驗醫學 雜誌第 23 焱. 第 8 號., 同上. 第 24 卷. 160 頁) 今回八其，兩物質二關 三 有機分 析ノ結果報告スル(表省略)。更二鳥型 結核菌培養滤液チ牛型菌二於ヶルト全ク 同一ノ方法デ分劃シテ其，作用キ檢シタ ノデ此處二報告スル。

表ノ如ク傳研株鳥型結核菌于 Sauton 合成培地 $=37^{\circ} \mathrm{C}, 12$ 日間培養シ其, 滤液

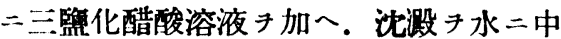
和溶解シ之レ二燐「ウォルフラム」酸き使 用シ最後二等電點シ利用シテえレカラ 3 ツノ分劃部分チ得タ (I, II, III)。三監化 醋酸上清カラ八燐「ウ‡ルフラム小酸子使 用シ 2 ッ分劃部分テ得タ (IV, $\mathbf{\nabla})$ 。 牛型結核感染海猽二對 シテハI, II, III 


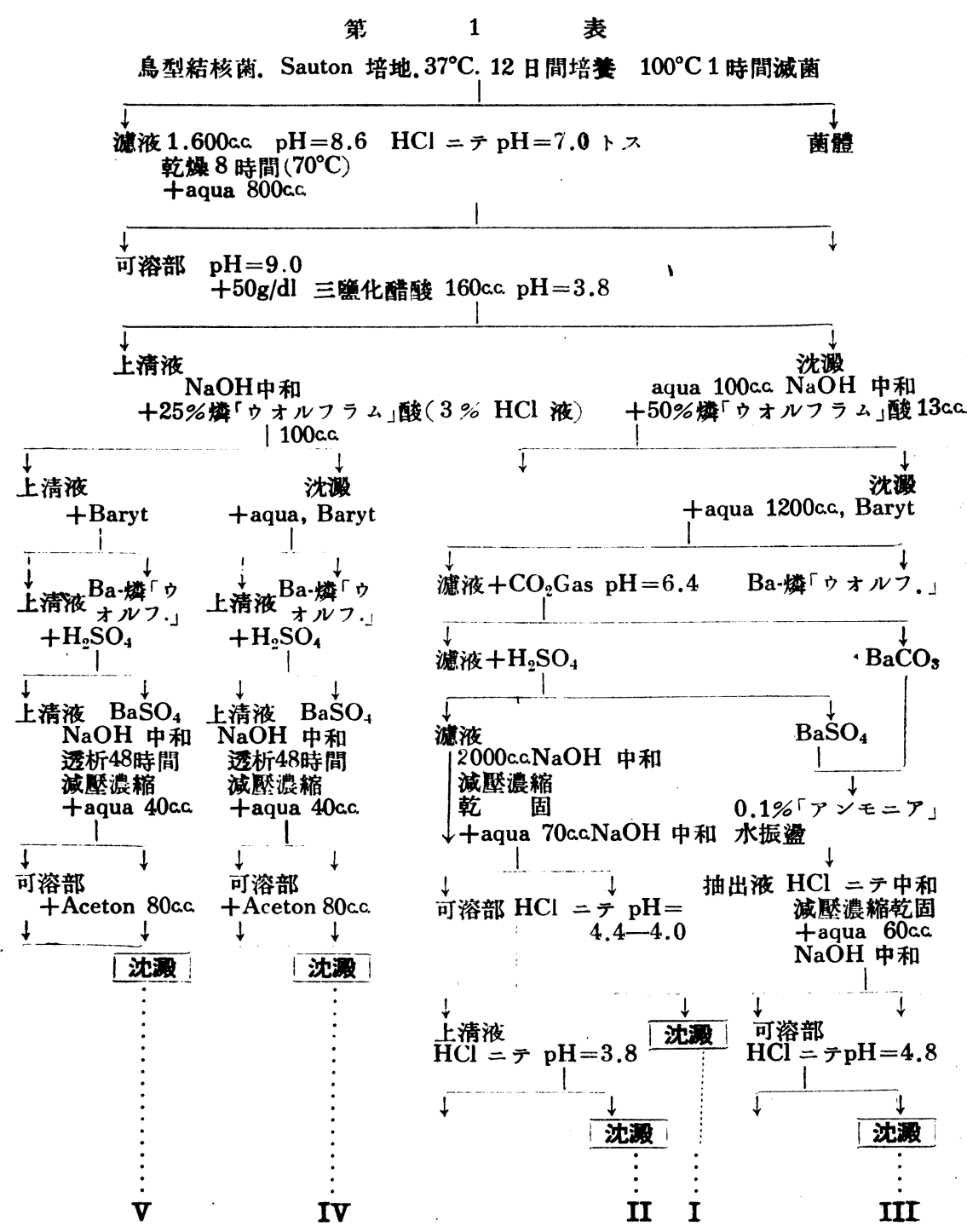

ハ $1 \mathrm{mg}$ デ 24 時間目二明暸ナル皮內反 應キ認メタガ. 48 時間デハ悉ク消螁スル チ見タ。IV. V 二於テハ $1 \mathrm{mg}$ デハ明カ ナ反應ハ 24 時間目二モ 48 時間目二モ認 メルコトハ出來ナカッタ。反之牛型結核 菌カラノ皮萑物質ハ $0.01 \mathrm{mg}$ デ 48 時間 目 $=1.2 \times 2.0 \mathrm{~cm}$ 直徑, 紅斑. 硬結米確
認シタ。I, II, III ノ 24 時間 ノ反應ハ 48 時間目二ハ跡方モ無ク消失スルコト カラ見ルト其レハ假性反應デアルカモ知 レナイ。郎チ此ノ場合二ハ牛型菌感染海 猽二ハ鳥型 Tuberkulin ハ反應七ズ反之 牛型 Tuberkulin 八强力二反應シテ居ル ト云へヨウ。 
鳥型菌キ接種シテ得タ感染冢鬼，皮內 ニ於テハI， $0.01 \mathrm{mg}$ デ $1.0 \times 1.0 \mathrm{~cm}$ 直徑ノ紅斑. 硬結き見. 牛型結核菌ノ皮虞 物質デハ $0.1 \mathrm{mg}$ ガ其ノ m.r.d. ナルコ 卜チ 48 時間目二認メルコトガ出來タ。

更二鳥型結核菌接種シタ感染海猽二 於テハI モ牛型結核菌ノ皮虔物質モ共二 48 時間目二ハ何等, 皮內反應き見ルコ トハ出來ナカツタ。

上述, 所見八 Bonnet, Thieffry et Montefiore ガ鳥型結核菌䉆. 家鬼. 湖 猽二感染七シメ之レニ牛型及ビ鳥型 $\mathrm{Tu}$ berkulin キ注射シテ得タ觀察ト極メテ ヨク一致シテ居ル。

$5 ッ ノ$ 分劃成分ハえレチ牛型結核菌感 染海猽, 腹腔二 $100 \mathrm{mg}$ チ注射スルモ就 レモ悉ク海猽整死七シメルコトハ出來 ナカツタ。

沈降反應カラ見ルト鳥型死菌キ以テ免 疫シタ家鬼血清トハI, II, III（三籃化醋 酸沈激) 八各々 1000 倍溶液 (生理的食監 水溶液) マデ陽性二反應シ IV, V( . 監化 醋酸上清) 八 10 萬倍溶液 (牛理的食監水 溶液）二テ陽性二反應シテ居ル。此人尔 八牛型死菌免疫家鬼血清キ以テシテモ全 ク同樣デ其ノ間二區別チ設ケルコトハ出 來ナカツタ。磯氏モ同樣ノ結果テ得テ居 u。

色彩反應力ラ見ルト I, II, III 八其 $1 \%$ 二於于 Biuret, Ninhydrin, Molich, Millon, 坂口. Hopkins-Cole , 反應八 悉ク陽性デアッタ。

(傳染病研究所第二研究部 練谷研究宾二 於テ)

\section{昭和 15 年 4 月萖談侖演題站二} 要旨「フェノール」類及ビ

\section{芳香后酸類ノ殺薄作用}

鐵 本 總 吾

phenol 類, 殺菌作用二就イテハ. Bechhold, Ehrlich, Reichel, Schmidt, Morgan, Cooper, Schafer, Tilley, Klarmann, Lockemann, 黑明. 手塚等 頗儿多數ノ研究アリ。 叉 phenol 類ノ消 毒二就イテハ. Readeal, Walker, Reddish, 小息.中込. 小岛 (國康) 等頻儿多 數ノ報告アリ。然レドモ從來ノ多數ノ研 究八殆ド皆 phenol, cresol, tymol 及ビ Cl-phenol ，殺菌沙毒等二關入ルモノ= 限ラレタル觀アリ。芳香屬酸類八根. 䓠. 葉. 花. 果賽等二含マレテ，廣ク，自然界 二分布三古來日常生活卜梁キ關係斗 人。此八屬中 benzoic, salicylic, p-oHbenzoic, tannic 等諸酸, 殺菌防腐二就 イテハKoch, Bernacki, Walliczeck, Wehmer, Winslow, 黑田. 林田. Sabalitschka, 高橋 (佔造)，黑野. 加滕. 深井等 多數, 研究アリ。然レドモ從來, 研究八 殆ド皆 benzoic, salicylic, p-oH-benzoic tannic 等, 酸類, 殺荣乃主防腐作用, $i=$ 限ラレタル觀アリ。余八 phenol 類 及ビ劣香屬陖類于叮及的多數蒐集シ之等 于分子量. $\mathrm{OH}$ 基. $\mathrm{CO}_{2} \mathrm{H}$ 基，數順二 系統的二配列 $\equiv \mathrm{OH}$ 基. $\mathrm{CH}_{3}$ 基等, 位置 站二數卜殺菌作用. $\mathrm{pH}$ 非解離分子等卜 殺菌乃至菌, 生存助長作用卜，關係等于 研究 シ吏二化學構造卜殺菌乃至菌, 生存 助長作用卜ノ間二如何ナル關係アリヤソ , 關係, 起因如何等 石研究シテ下記, 所 兒端二考察タ得タリ。

(1) phenol 類及ビ芳香屬酸類ハ概衣 殺菌乃至菌ノ生存阻止作用于有入。此 ，作用，起因八各試樂， $\mathrm{pH}$. 非解蜼分 子. 证二 $\mathrm{pH}$ 卜韭解離分子卜，共同， 
作用二基ク。但 シ guajacol, resorcin, phloroglucin, tele-phthal 酸等極メテ少 數ノ試䒚ハ供試細菌二對シテ著明ナル生 存助長作用示ス。

(2) phenol 類二於テハ picri i 酸 tymol, hydroquinon, 三者, 殺菌作用八 頗ル大ナレドモ他八殺菌作用微弱ナルカ 或八全ク殺菌作朋ナシ。芳香屬酸類二於 テハ salicyl 酸以外二特二强烈ナル殺菻 “作用チ有スルモノ無キガ如シ。然レドモ 數多, 高級脂肪酸類. phenol 類二於ヶル ガ如ク供試菌ノ生你助長作用チナスモ， 八無シ。

（3）化學構选卜殺菌作朋卜）關係八次 , 如 シ. phenol 類, 同分異種體近二異 性體間, 殺菌作用, 强度》 $\mathrm{m}<\mathrm{o}<\mathrm{p}$ 。 halogen 及ビ NO.phenol 類二於テハ $0<\mathrm{m}<\mathrm{p}$ 。 benzoic acid $¥$ 母體卜ス儿芳 香屬酸類二於テ， $\mathrm{m}<\mathrm{p}<\mathrm{o}$ 。 phthal 酸 類二於テ八 tele <iso<normal。郎于化 學構造卜殺菌乃至菌, 牛位阴止作湖卜， 間二密接ナル關係保作入。

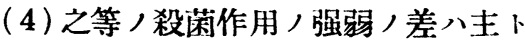
シテ benzene 核二結合セル $\mathrm{CH}_{3}$ 基. $\mathrm{OH}$ 基. halogen 元素. $\mathrm{NO}_{2}$ 基. $\mathrm{CO}_{2} \mathrm{H}$ 基等, 位置ニョリ各試樂, 分子人作用二 强弱ノ差ノ生ゼシ䉆卜解七ラル。

(5) 而シテ phenol 類及上"妿香屬酸類 ノ分子ノ作用二カ、儿强弱, 差ノ起儿理 由八各異性體子構成スル基又心元素ノ種 類. 位置. 等ニョッテ各異性體, 闲體原 形質二對スル吸著量乃至菌體二ヨル消費 量二多少ノ差キ生ズル第メニョル。

\section{BCG 接種後ノ「ツベルクリン」 \\ 反矿ノ消畏卜 BCG 接種者二

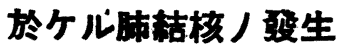

岡 西順二郎

「ッ」反應陰者ノ看膵婦 接種シ。「ッ」反應 狀態キ $1-4$ 年間追
究シ得タ 72 名二就テ觀察シ. 又 $B C G$ 接 種者二於ヶル肺結核發生 く狀態 調查 シ。次ノ如キ結果得タ。

BCG キ接種シテ 1ー3 ケ月後二「ッ」反 憵ガ陽性轉化シ. 1 年後再ビ陰性トナリ シ者ハ 13 例 $(18 \%)$ デ。其ノ中ョリ 1 名 $(7.7 \%)$ 滲出性肋膜炎二罹患ショ。 BCG キ接種シテ 1-3 ケ月後「ッ」反應力゙陽性 轉化 シ. 其後 1-4 年間其狀態 繼續七 ル者ハ 37 例 $(51.4 \%)$ デ．其中ョリ 4 名 $(10.8 \%)$ 結核性疾患二罹患シタ。BCG 接 種後 4-12 ケ月二シテ始メテ「ッ」反應が 陽轉シタ者ハ 12 名 $(16.7 \%)$ デ.此ノ中ヨ リ 3 名 $(25.0 \%)$ 結核性疾患トナリ. BCG 接種後 1 年以上キ經ルモ「ツ」反應ガ陰性 二留ルカ. 或八時卜転度八陽性反應. 疑性 反應キ呈スル者ハ10名(13.9\%)デ.此ノ 中ョリ 2 名 $(20.0 \%)$ 罹患シタ。BCG キ再 三接種シテモ「ツ」反應が陽轉シナカッタ 者ガ 7 名 $(9.7 \%)$ アッタ。BCG接種後 3 ケ 月以內二「ッ」反應が陽轉七シ者ノ發病华 ハ $10 \%$ デ. えォ 3 ケ月以內二陽轉セザッ シ者ノ發病率 $22.7 \%$ 二比較スルト著シク 少イ。BCG キ接種セズシテ「ッ」反應ノ陽 性轉化セル 16 名中 8 名八發病シ.之二比 シテ $\mathrm{BCG}$ 接種者八發病率八著シク少イ。

以上ニヨリ結核感染ノ機會,湿厚ナ看 護婦二對シテ BCG キ接種スレバ. 其ノ 發病チ相當, 程度防止シ得ル事キ知ツ 夕。倘又一度陽性轉化シテモ。後再ビ陰性 トナル場合ガアルカラ BCG 接種者八絕 エズ「ツ」反應シ检查スル必要がアルシ. $\mathrm{BCG}$ 接種後 3 ケ月以內二陽轉シナ1者 二對シテハ再三接種き絽返入必要ガア゚ル 卜思フ。更二 BCG キ再三. 接種シテモ 「ツ」反應ノ陽轉シナイ者が約 $10 \%$ アツ 夕事ハ注目スベキデ。斯カル人々二八接 種量增スカ，接種方法變へル必要ガ アルト思七。現在砰究中デアル。 